\title{
Potentials of mangrove ecosystem as storage of carbon for global warming mitigation
}

\author{
ADILAH DINILHUDA ${ }^{1}$, AJI ALI AKBAR ${ }^{1, \boldsymbol{v}}$, JUMIATI $^{1}$, HENNY HERAWATI $^{2}$ \\ ${ }^{1}$ Department of Environmental Engineering, Faculty of Engineering, Universitas Tanjungpura. Jl. Prof. Dr. H. Hadari Nawawi, Pontianak 78124, West \\ Kalimantan, Indonesia. Tel.: +62-721-740186, •email: aji.ali.akbar.2011@gmail.com \\ ${ }^{2}$ Department of Civil Engineering, Faculty of Engineering, Universitas Tanjungpura. Jl. Prof. Dr. H. Hadari Nawawi, Pontianak 78124, West Kalimantan, \\ Indonesia
}

Manuscript received: 15 August 2020. Revision accepted: 24 October 2020.

\begin{abstract}
Dinilhuda A, Akbar AA, Jumiati, Herawati H. 2020. Potential of mangrove ecosystem as carbon storage for global warming mitigation. Biodiversitas 21: 5353-5362. The mangrove ecosystem in Karimunting Bay of West Kalimantan, Indonesia is one of the conservation areas with an area of 138.2 ha. Vegetation making up of that mangrove ecosystem is dominated by Avicennia marina. The existence of mangroves has a role in carbon storage. The ability to store carbon in mangrove forest ecosystems is four times greater than in other tropical forests around the world. Mangrove stems have the greatest ability in storing carbon by up to 55.52\%. The research objective was to analyze the potential for carbon storage in the fringe mangrove ecosystem which was dominated by A. marina. This research method is based on a survey of vegetation density in the field. The survey was carried out in Karimunting Bay in three parts of the bay, north, central, and south. Each part of the bay consists of two locations, namely at the front of the breakwater towards the sea and behind the breakwater towards the land. Each location consisted of a plot of $10 \times 10$ with five replications. The vegetation parameters measured are the types of growth forms, the mangrove ecosystem species, and the diameter and height of the trees, as well as environmental parameters $(\mathrm{pH}$, temperature, and salinity). Destructive method was used on A. marina stems for estimating analysis of mangrove carbon storage in the laboratory. A. marina stem samples were used to test the carbon content with LOI (Lost on Ignition) analysis. Analysis of changes in mangrove area is based on the 2009 and 2019 landscape images. The results show that the mangrove ecosystem of Karimunting Bay has a total density of 177,480 individuals/ha. The amount of carbon storage reached $99,231 \mathrm{mg} / \mathrm{ha}$ in 2019 and predictions of total carbon storage over the last 10 years are as much as 13,717,951 tons. Deposits of carbon in fringe mangrove illustrate the carbon dioxide absorption potential of 36,390,608 tons of $\mathrm{CO}_{2}$. The amount of $\mathrm{CO}_{2}$ absorption in fringe mangrove ecosystem type plays a role in reducing greenhouse gas (GHG) emissions with a conditional target according to the Nationally Determined Contribution (NDC) in 2030 of 834 million tons of $\mathrm{CO}_{2}$ to prevent temperature increases.
\end{abstract}

Keywords: Avicennia marina, carbon storage, mangroves, mitigation

\section{INTRODUCTION}

Mangrove forests provide economic, social, and environmental benefits such as fish nursery, timber production, water filtration, carbon sequestration, recreation, and education (Wang et al. 2018). But the important role of mangroves does not guarantee their sustainability and changes in land use and damage in various regions. This is caused by the community not being aware of the value of mangrove ecosystem services to the environment (Vo et al. 2015). The condition of the mangrove forest ecosystem in Karimunting Bay as a conservation area was damaged. The cause of damage to mangrove ecosystems is caused by natural abrasion and is aggravated by land-use changes. Abrasion occurring along the coastline of West Kalimantan has damaged mangrove ecosystems up to $20 \mathrm{~m} / \mathrm{year}$ for the past 40 years. Changes in land use which also contributed to the destruction of mangrove ecosystems were triggered by rapid reclamation, an increase in coconut plantations and settlements since the 1950s, followed by extensive shrimp pond expansion in the early 1980s (Akbar et al. 2017). Damage to the mangrove ecosystem plays a role in changing the coastline to reverse
(Ritohardoyo et al. 2017).

Mangrove ecosystems services are similar to other forest ecosystems, namely carbon sinks. Nearly $40 \%$ of tree biomass is carbon. The process of photosynthesis is one of the processes in trees, namely the process of absorbing carbon dioxide from the atmosphere and converting it into organic carbon (carbohydrates) and storing it in their body biomass such as in stems, leaves, roots, tubers, fruit, etc. The method that can be used to determine carbon storage is to calculate the biomass of the plant (Rahmah et al. 2014). Biomass from carbon sequestration is a forest service as an effort to restore the environment by reducing $\mathrm{CO}_{2}$ in the atmosphere. Loss of the mangrove ecosystem will be a source of large amounts of carbon release for the greenhouse impact (Sondak et al. 2015).

The condition of the mangrove in Karimunting Bay based on two criteria for mangrove damage from the Minister of Environment Decree No. 201 of 2004 indicates that it is in a severely damaged category, with a density value of <1000 stands/ha. Akbar et al. (2017), also added that Karimunting Bay had experienced a period of coastal damage due to considerable abrasion. Abrasion has resulted in damage to mangroves on the West Kalimantan coast. 
One of the impacts of mangrove forest destruction is the release of greenhouse gas emissions into the atmosphere. Estimation of carbon calculation is necessary to assess the potential for carbon storage in the marginal mangrove ecosystem to mitigate global warming. This potential in an ecosystem or mangrove area can provide an overview of the impacts that will be caused.

Broadly speaking, the impact caused by mangrove damage is that it plays a role in global warming. Mangroves have the potential to store global carbon stocks up to $956 \mathrm{Mg} \mathrm{C}$ per ha which is greater than rain forests, peat forests, salty swamps, and seagrass beds (Alongi 2014). The existence of mangroves, which is only around $1 \%$ of the world's coastal areas, has a role of up to $20 \%$ of carbon storage. Mangrove damage certainly has a big impact on carbon storage and nutrients for ecosystems (Perez et al. 2018). Mangroves as carbon storage play a role in storing $10 \%$ of total carbon and $25 \%$ of carbon storage in the world's coastal zones. Estimation of carbon calculations needs to be done to determine the potential for carbon storage and release. This potential in an ecosystem or mangrove area can give an idea of the impact that will be caused (Eid and Shaltout 2015).

According to Ewel et al. (1998), there are three types of mangrove ecosystems namely mangrove edge, mangrove, and mangrove river basin which have each featured environmental service. River and basin types of mangroves have a large diversity of mangrove species and produce wood, while these types of mangroves are better known for their environmental services as coastal protection. The decline in the area of mangrove forest ecosystems is associated with carbon sequestration and storage that play a role in climate change (Liu et al. 2014). The importance of estimating the potential for carbon storage in mangrove vegetation as mitigation of global warming, makes a signal to conserve the mangrove ecosystem (Chow 2017). This study aims to determine the vegetation density of mangrove ecosystems, estimation of carbon storage potential on mangrove stems, analyze the correlation between area and potential of fringe mangrove storage, and analyze the correlation between potential mangrove storage and the mitigation of global warming along the coast that have the type of fringe mangroves.

\section{MATERIALS AND METHODS}

\section{Research location}

Determination of research location was based on the physical condition of mangrove forests, accessibility of transportation, vegetation density, and the presence of breakwater. The method used was the transect line plot in 3 coastal parts of Karimunting Bay, Bengkayang District, West Kalimantan Province, Indonesia. The research location was at $0^{\circ} 43^{\prime} 58.88$ "U-0 $0^{\circ} 47^{\prime} 18.47^{\prime \prime} \mathrm{U}$ and $108^{\circ}$ $52 ' 54.30$ "T-108 51'56.85" T. Sampling was carried out at 3 locations namely Block I $\left(0^{\circ} 43^{\prime} 58.88\right.$ "U and $108^{\circ}$ 52'54.30" T), Block II ( $0^{\circ} 46^{\prime} 20.60$ "U and $108^{\circ} 52^{\prime} 46.22^{\prime \prime}$ T) Block III $\left(0^{\circ} 47^{\prime} 18.47\right.$ "U and $\left.108^{\circ} 51^{\prime} 56.85^{\prime \prime} \mathrm{T}\right)$. The selection of plot points used random sampling.

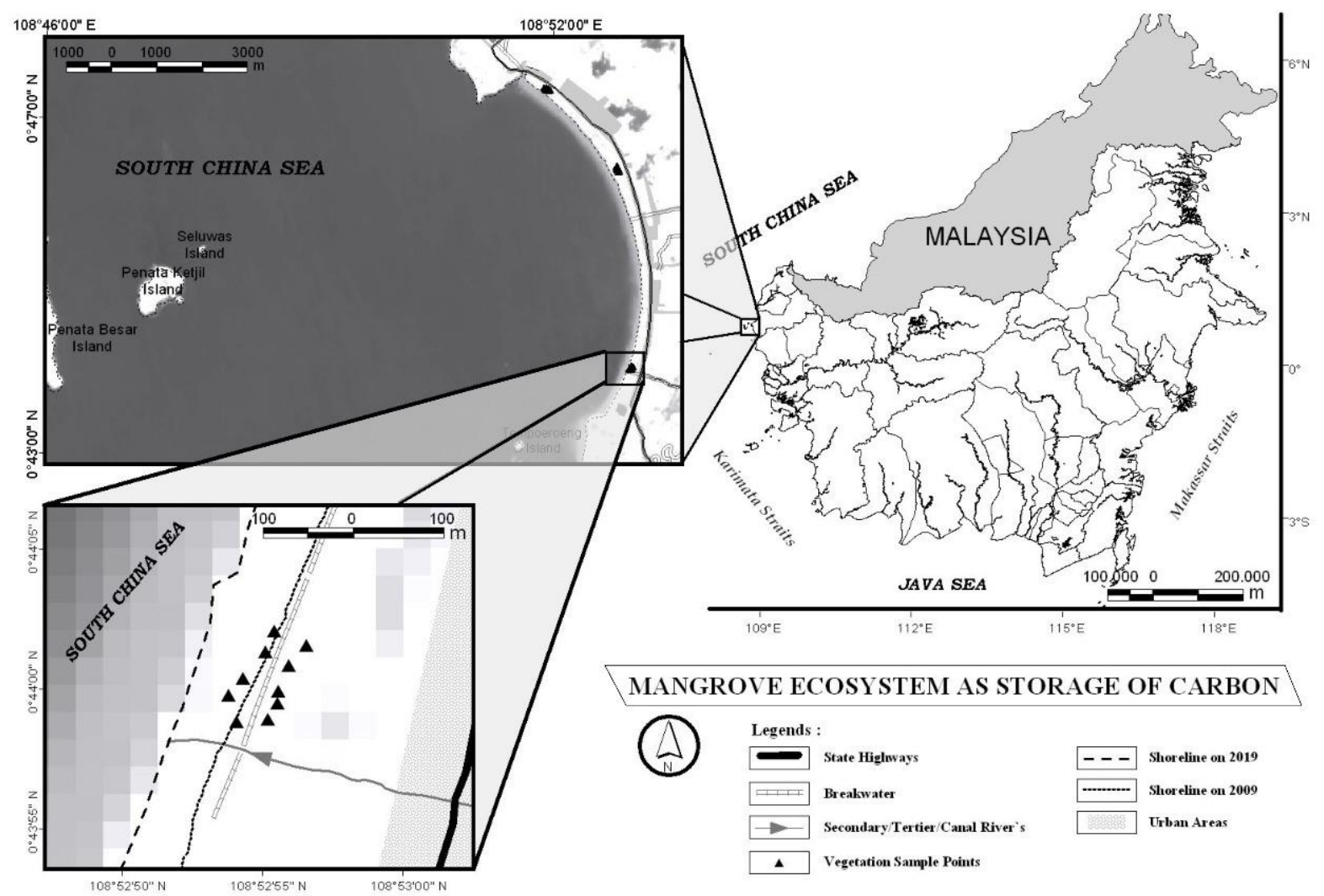

Figure 1. Research location in Karimunting Bay, Bengkayang District, West Kalimantan, Indonesia 


\section{Sampling plots}

The sampling plots used were 30 plots. Each plot is 10 $\mathrm{m} \times 10 \mathrm{~m}$ to illustrate the condition of the study site. Each block has 10 plots with 5 plots in the section after breakwater (land that is still exposed to the waves directly) and 5 plots divided before breakwater (The land that has been protected by the breakwater so that it is not directly exposed to waves). The coordinates are taken on each block and plot using handheld GPS (Garmin GPSMAP $78 \mathrm{~s}$ ). The coordinates of the block serve as the boundary of the study area. The study area is in the basin area which will be divided into 3 study blocks, namely Block I, Block II, and Block III (Prasetyo et al. 2017). The distance between the blocks cannot be equated because the area in the middle there is a community disturbance with the conversion of land into coconut plantations.

\section{Vegetation inventory}

Vegetation inventory is used to describe species diversity in mangrove forests. According to English et al. (1994), the form of mangrove growth is divided into 3 namely trees, saplings, and seedlings. The form of tree growth has a height of $>1 \mathrm{~m}$ with a diameter of $>4 \mathrm{~cm}$. Mangrove saplings have a height of $>1 \mathrm{~m}$ with a diameter of $<4 \mathrm{~cm}$. While seedlings have a height of $<1 \mathrm{~m}$ and a diameter of $<4 \mathrm{~cm}$. Vegetation inventory is carried out in the sample plot by counting the number and measuring the diameter, height, and area of the vegetation canopy. In addition to the inventory, each Avicennia marina mangrove stem has been sampled. For each block, 2 pieces of $30 \mathrm{~cm}$ wood sample (Gillerot et al. 2018) were taken which represented the carbon content of the mangrove trunk. The test method used is the LOI (Loss on Ignition) method by calculating the levels of organic material in the sample and the standard beam size of the test based on British Standard No. 373 of 1957 which has been adjusted.

\section{Data analysis}

Forest structure and composition

Mangrove ecosystem conditions can be described by calculating density, dominance, frequency, and measurement of environmental parameters $(\mathrm{pH}$, temperature, and salinity). Estimation of density (individual/ha), frequency $(\%)$, basal area $\left(\mathrm{m}^{2}\right)$, and dominance $(\%)$ can be identified by collecting measurement data directly in the form of vegetation, diameter $(\mathrm{cm})$, height $(\mathrm{m})$, and canopy area $(\mathrm{cm})$ (Prasetyo et al. 2017). Field data that have been collected will be analyzed using calculations (English et al. 1994). Measurement of environmental parameters is useful to determine the effect of environmental conditions on the growth and development of mangroves. Temperature measurement (air and soil) uses a thermometer. Measurement of water $\mathrm{pH}$ uses a $\mathrm{pH}$ meter. Whereas salinity measurements use a refractometer.

Calculations of the estimated number of tree trunks growing in sampling area (English et al.1994) are as follows:
Basal Area $(B A)=\frac{\pi D B H^{2}}{4}=m^{2}$

So, correlation between density, dominance, and frequency according to these formulae:

$$
\begin{aligned}
& \text { Density }=\frac{\text { number of individuals of a species }}{\text { sampling area }\left(\mathrm{m}^{2}\right)} \\
& \text { Density }\left(\frac{\text { indv }}{1000 \mathrm{~m}^{2}}\right)=\frac{\text { Density } \left.\frac{\text { indv }}{3000 \mathrm{~m}^{2}}\right)}{a} \\
& \text { Relative Density }(\%)=\frac{\text { number of individuals of a species }}{\text { Total of number individuals all species }} \times 100 \\
& \text { Dominance }=\frac{\text { BA }}{\text { sampling area }\left(\mathrm{m}^{2}\right)}
\end{aligned}
$$$$
\text { Relative Dominance }(\%)=\frac{\text { basal area of a species }}{\text { basal area of all of species }} x 100
$$

Frequency $=\frac{\text { Number of sampling area (plot) of finding species }}{\text { Total of number sampling area }}$

Relative Frequency $(\%)=\frac{\text { frequency of a species }}{\text { Total frequency of all species }} x 100$

\section{Biomass estimation}

Biomass estimation is done by using several calculations using vegetation diameter, vegetation height, and specific gravity data to be converted into vegetation biomass values. The results of the biomass value will be converted into carbon storage values using the formula (SNI 7724: 2011). Density testing is only done on dominant vegetation types which are the type of $A$. marina. Calculating the carbon content uses the specific gravity of A. marina from the results of the laboratory analysis. While these types of mangrove Rhizophora and Bruguiera use the density of research Bismark et al. (2008). Rhizophora specific gravity is $0.92 \mathrm{~g} / \mathrm{cm}^{3}$ (Bismark et al. 2008) and Bruguiera is $0.91 \mathrm{~g} / \mathrm{cm}^{3}$ (Bismark et al. 2008). Measurement of specific gravity uses a $5 \times 2 \times 2$ beam that has been modified (British Standard No. 373 of 1957 in Elzaki and Khider 2013). The measurement of specific gravity is based on the ratio of the weight of the mangrove beam that has been in the oven with the change in volume (Alavaisha and Mangora 2016). Measurement of the sample volume uses a caliper which has an accuracy of $0.001 \mathrm{~cm}$, so that it is more detailed for the results of the measurements.

Calculations based on the type of mangrove carbon content can be calculated with the formula (SNI 7724:2011):

Tree volume calculation

$$
v=\frac{1}{4} \pi\left(\frac{D B H}{100}\right)^{2} \times t \times f
$$

Where:

$\begin{array}{ll}\mathrm{t} & : \text { Tree height }(\mathrm{m}) \\ \mathrm{f} & : \text { Form Factor }(0.6)\end{array}$ 


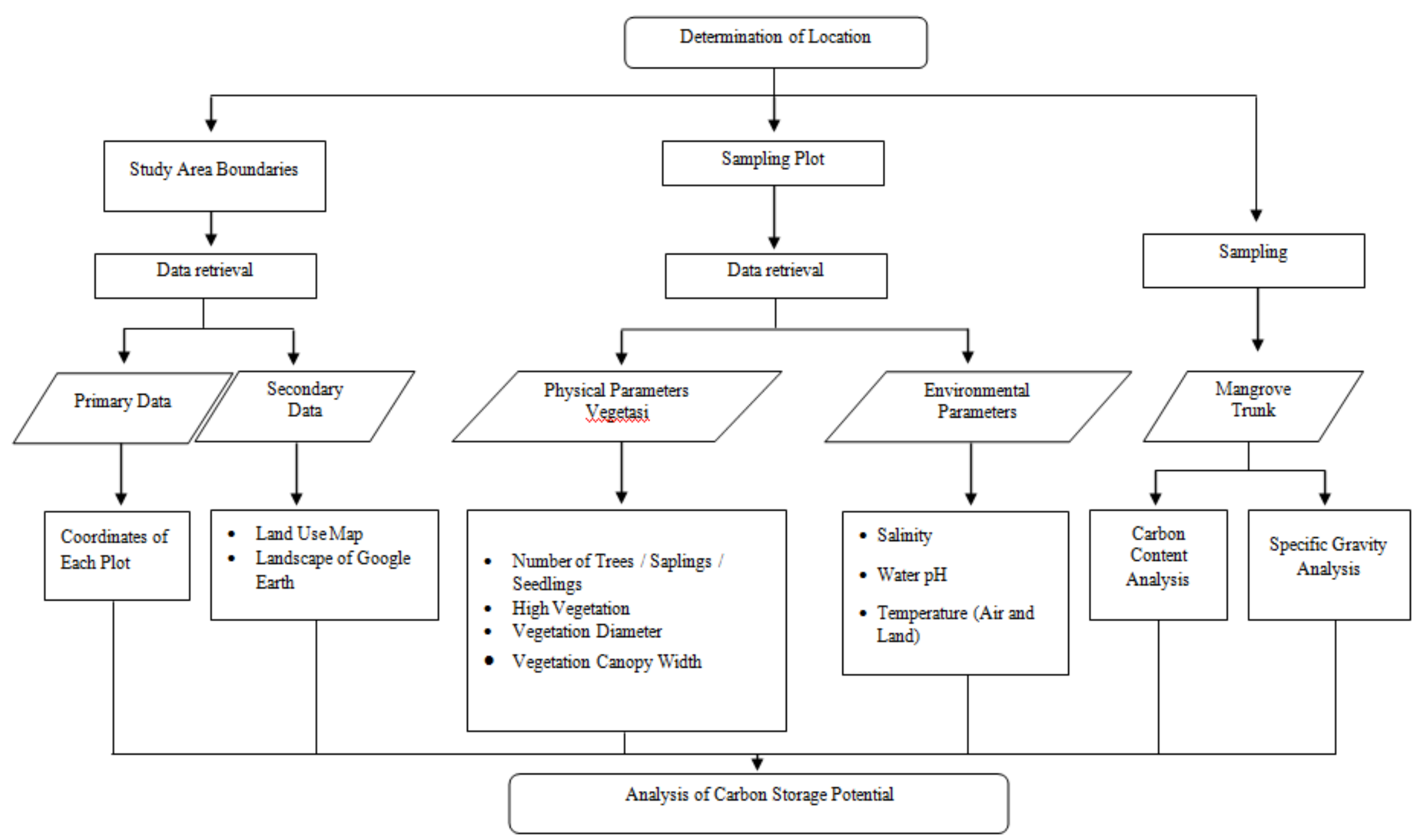

Figure 2. Research flow chart of mangrove carbon storage 
Biomass Expansion Factor (BEF) calculation according to Sutaryono (2009):

$$
\mathrm{BEF}_{\text {tegakan }}=\operatorname{Exp}[3.213-0.506 \times \ln (\mathrm{BV})]
$$

Where: The calculated BEF value is used if BV $<190$ ton/ha. If the $\mathrm{BV}$ is $\geq 190$ ton/ha then $\mathrm{BEF}=1.74$.

Stand Biomass (BV) according to the Forestry Research and Development Agency, (2013):

Stan biomass $=$ rod volume $\mathrm{x}$ specific gravity

$$
B V=\frac{\sum(\text { stand biomass })}{\text { area }}
$$

Where:

Stand biomass: Biomass-based on stand volume (mg/ha)

Area : Sample area (ha)

Specific gravity: Specific gravity each species (ton $/ \mathrm{m}^{3}$ )

Explanation of specific gravity:

Avicennia: $0.38-0.85 \mathrm{~g} / \mathrm{cm}^{3}$ (Baderan 2017)

Rhizopora : $0.92 \mathrm{~g} / \mathrm{cm}^{3}$ (Bismark et al. 2008)

Bruguiera: $0.91 \mathrm{~g} / \mathrm{cm}^{3}$ (Bismark et al. 2008)

Nypah: 0.87-1.19 g/cm (Syabana and Widiastuti 2018)

Biomass calculation according to the Forestry Research and Development Agency, (2013) is as follows:

Tree biomass $=\mathrm{BV} \times \mathrm{BEF}$

Where:

Tree Biomass: Tree Biomass ( $\mathrm{mg} / \mathrm{ha}$ )

Calculating of carbon content (SNI 7724:2011):

$\mathrm{Cb}=$ Tree biomass $\mathrm{x} \% \mathrm{C}$-organic

Where :

$\mathrm{Cb}$ : Carbon content of biomass ( $\mathrm{mg} / \mathrm{ha})$.

B : Total biomass, expressed in ( $\mathrm{mg} / \mathrm{ha})$.

$\% \mathrm{C}$ organic: The value of the percentage of carbon content, equal to 0,47 or using the percent carbon value obtained from the measurement results in the laboratory.

Carbon stock calculation

Carbon stock $=$ Carbon biomass $(\mathrm{Cb}) \mathrm{x}$ area

Where:

Area : The total area studied (138.2 ha)

Calculation of area increase

Increase in area $=$ End year area - Early years area

Total area added $=$ Addition of final area+Initial area addition (18)

Carbon storage
Carbon storage $(5 \mathrm{yrs})=$ early years area $\mathrm{x}$ total carbon storage $(19)$

Addition of carbon deposits $=$ difference in addition area (2009-2014) x total carbon storage

Conversion value of carbon (C) to carbon dioxide $\left(\mathrm{CO}_{2}\right)$ according to Agus et al. (2011):

$\mathrm{CO}_{2}=\mathrm{C}$ (carbon) $\mathrm{x} 44 / 12$

Where :

$\mathrm{C}$ (Carbon) : Total carbon storage (ton) or (mg)

\section{Carbon estimates}

The carbon potential of each mangrove species is different and can be determined based on the specific gravity of each mangrove species and the percentage of carbon content. Testing the percentage of carbon content (\% C) in the mangrove stem aims to convert the amount of carbon stored in the mangrove stem. Analysis of the percentage of carbon content in mangrove stems uses LOI (Loss on Ignition) method. The principle of this method is by weighing the wet weight, dry weight, and heating in a furnace with a temperature of $500^{\circ} \mathrm{C}$ for 6 hours (Kreeger et al. 2010). Carbon estimation for each type of vegetation is obtained from the multiplication of biomass and carbon content (\% C) of each type. The amount of carbon estimates in the sample plot will represent carbon storage per hectare. The carbon content value per hectare will be converted to an area of 138.2 ha in the study area.

\section{Modeling of carbon storage potential}

The influence of mangrove areas on carbon storage can be seen from the correlation of the addition of mangrove ecosystem land in Karimunting Bay. The analysis was carried out using the help of Google Earth and ArcGIS 1.0 software. The secondary data needed in the form of Bengkayang District land use map were obtained from the Regional Development Planning Agency (Bappeda) of West Kalimantan and mangrove forest area digitization in 2009, 2014, and 2019. The results are in the form of a correlation map between the rate of development and the potential for carbon storage in the mangrove area of Karimunting Bay, Bengkayang District.

\section{RESULTS AND DISCUSSION}

\section{Parameter value of mangrove forest}

The results showed that there was 6 mangrove vegetation found on the coast of Karimunting Bay, namely Avicennia marina, Bruguiera gymnorrhiza, Nypa fruticans, Rhizophora stylosa, Derris trifoliata, and Sesuvium portulacastrum (Table 1).

\section{Carbon storage potential}

Carbon storage is directly proportional to the area of mangrove forest. The wider the mangrove forest, the more carbon storage, and the less carbon release. This is because 
more mangroves in the area will absorb and then store carbon. Excellent carbon storage occurs in leaves, branches, stems, roots and soil (Hong et al. 2017). The potential for carbon storage is directly proportional to the amount of biomass in the vegetation (Rahmah et al. 2014). The data in Table 2 describes the parameters calculated to determine the potential amount of carbon stored. Based on Table 2, the total carbon potential in the fringe mangrove ecosystem at Karimunting Bay is 99,231 mg/ha. The largest number comes from the species $A$. marina about $79,782 \mathrm{mg} / \mathrm{ha}(80 \%)$ which is influenced by the density of the $A$. marina species stands.

The calculation results are supported by modeling that can describe changes in the increase in mangrove area. The condition of the Karimunting Bay mangrove forest from 2009 to 2019 has changed as shown in Figure 3.

Table 1. Parameter value of mangrove forest Karimunting Bay, West Kalimantan Province, Indonesia

\begin{tabular}{lcccccc}
\hline \multicolumn{1}{c}{ Species } & $\begin{array}{c}\text { High } \\
(\mathbf{m})\end{array}$ & $\begin{array}{c}\text { Diameter at breast } \\
\text { height }(\mathbf{c m})\end{array}$ & $\begin{array}{c}\text { Basal area } \\
\left(\mathbf{m}^{\mathbf{2}}\right)\end{array}$ & $\begin{array}{c}\text { Density } \\
\left(\mathbf{i n d} / \mathbf{1 0 0 0} \mathbf{~ m}^{\mathbf{2}}\right)\end{array}$ & $\begin{array}{c}\text { Relative } \\
\text { dominance }(\boldsymbol{\%})\end{array}$ & $\begin{array}{c}\text { Relative } \\
\text { frequency }(\boldsymbol{\%})\end{array}$ \\
\hline Avicennia marina & 5.77 & 4.50 & 0.301 & 614 & 95.75 & 42.86 \\
Bruguiera gymnorrhiza & 3.26 & 2.79 & 0.004 & 14 & 1.25 & 21.43 \\
Rhizophora stylosa & 4.47 & 4.52 & 0.009 & 31 & 3.00 & 15.71 \\
Nypa fruticans & 0.77 & - & - & 1 & - & 1.43 \\
Derris trifoliata & 0.21 & - & - & 14,801 & - & 11.43 \\
Sesuvium portulacastrum & 0.08 & - & - & 2,233 & - & 7.14 \\
Total (average) & & $(3.94)$ & 0.315 & 17,748 & 100 & 100
\end{tabular}

Table 2. Potential carbon storage parameters of Karimunting Bay, West Kalimantan, Indonesia

\begin{tabular}{|c|c|c|c|c|c|}
\hline \multirow{2}{*}{ Parameter } & \multirow{2}{*}{ Unit } & \multicolumn{3}{|c|}{ Type of vegetation } & \multirow{2}{*}{ Total } \\
\hline & & Avicennia marina & Bruguiera gymnorrhiza & Rhizophora stylosa & \\
\hline High & $\mathrm{m}$ & 5.77 & 3.26 & 4.47 & 4.50 \\
\hline Diameter at Breast Height (DBH) & $\mathrm{cm}$ & 4.50 & 2.79 & 4.52 & 3.94 \\
\hline Specific gravity & $\mathrm{g} / \mathrm{cm}^{3}$ & $0.71 *$ & $0.91 * *$ & $0.92 * *$ & - \\
\hline Fraction $* * *$ & - & 0.6 & 0.6 & 0.6 & - \\
\hline Volume of logs & $\mathrm{m}^{3}$ & 0.006 & 0.001 & 0.095 & - \\
\hline BV & $\mathrm{mg} / \mathrm{ha}$ & 34.89 & 0.75 & 0.64 & - \\
\hline BEF & & 4.12 & 28.84 & 31.23 & - \\
\hline Stand biomass & $\mathrm{mg} / \mathrm{ha}$ & 143.70 & 21.49 & 19.89 & - \\
\hline$\% \mathrm{C}$ (carbon) & & $0.5552 *$ & $0.47 * * *$ & $0.47 * * *$ & - \\
\hline Biomass carbon & $\mathrm{mg} / \mathrm{ha}$ & 79,782 & 10,101 & 9,347 & 99,231 \\
\hline Carbon reserves & Ton & & $13,713.717$ & & \\
\hline
\end{tabular}

Tabel 3. Correlation between expansion of mangrove ecosystem area and carbon storage

\begin{tabular}{lcll}
\hline No & Year & Land area (ha) & $\begin{array}{l}\text { Carbon } \\
\text { storage (ton) }\end{array}$ \\
\hline 1 & 2009 & 38.32 & $3,802,254$ \\
2 & 2014 & 59.25 & $5,879,248$ \\
3 & 2019 & 138.24 & $13,717,951$ \\
Average per years & & 991.570 \\
\hline
\end{tabular}

\section{Discussion}

Mangrove ecosystem conditions

Environmental factors and human activities play a role in the addition of mangrove vegetation (Alavaisha and Mangora 2016). Species diversity is influenced by the ability of vegetation adaptation to environmental factors such as $\mathrm{pH}$, temperature, and salinity so that only certain vegetation is able to adapt and survive (FAO 1994). Human activities in land-use change also influence mangrove diversity (Gillerot et al. 2018). Each type of mangrove has a different density value. The density of an ecosystem can
Tabel 4. Environmental parameters

\begin{tabular}{lccc}
\hline Blok & pH & $\begin{array}{c}\text { Temperature } \\
\left({ }^{\mathbf{0}} \mathbf{C}\right)\end{array}$ & Salinity (\%o) \\
\hline I & 8.2 & 29.3 & 34 \\
II & 7.5 & 32.2 & 26 \\
II & 7.6 & 29.3 & 30 \\
\hline
\end{tabular}

be seen from the physical condition of mangrove vegetation. The condition is in the form of environmental activities that can be identified from several parameter values such as stem diameter, height, dominance, relative dominance, frequency, relative frequency, and canopy area (Prasetyo et al. 2017). The amount of density is determined based on the number of individuals of a type divided by the area of the sample. The 6 types of vegetation found at the study site have different densities. The results of the calculation of the entire sample plot can be seen in Table 1. 

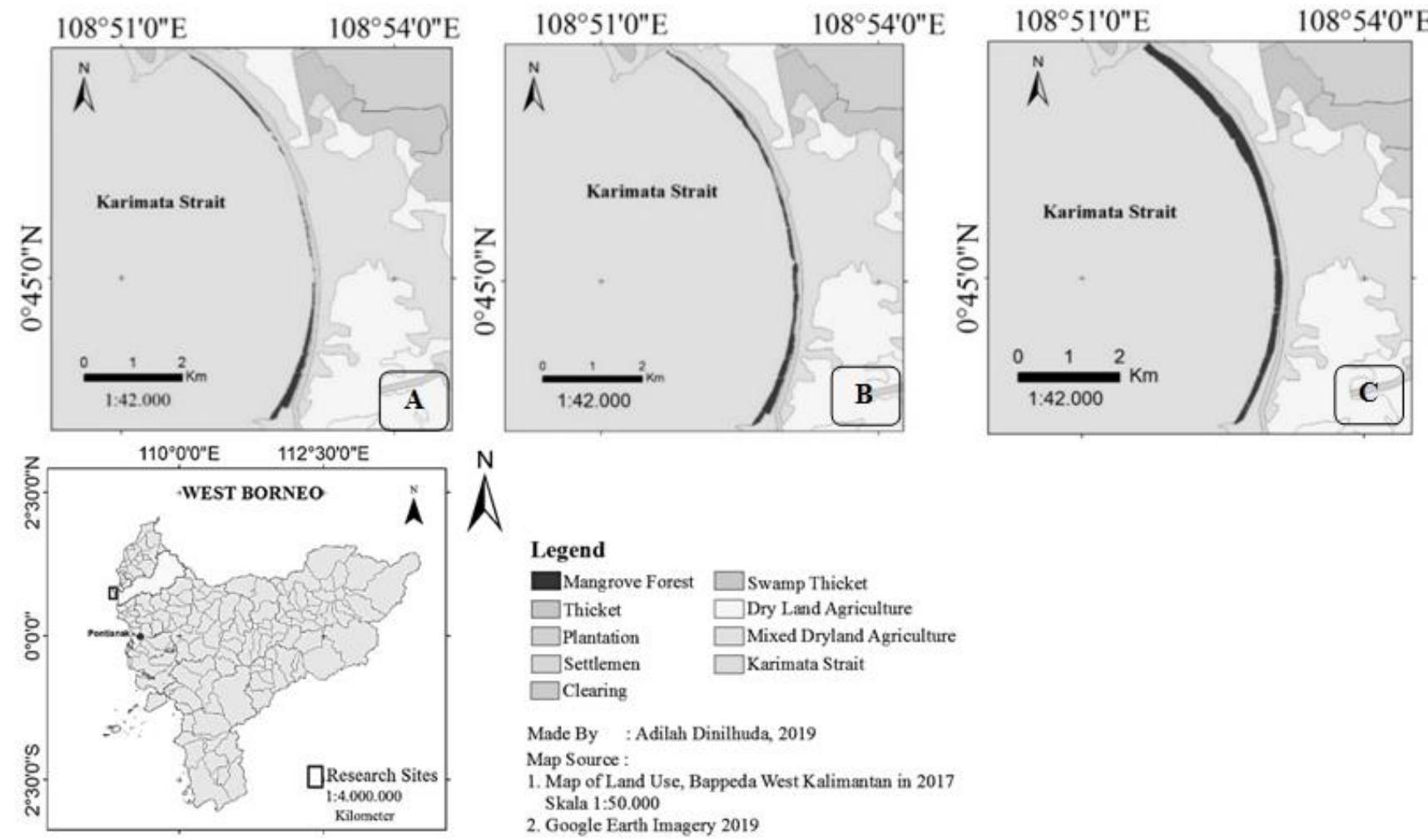

Figure 3. Mangrove area expansion in: A. 2009, B. 2014, C. 2019

Mangroves are divided into 2 types namely true mangroves and associated mangroves (Kerte et al. 2014). True mangrove species are A. marina, Bruguiera gymnorrhiza, and Nypa fruticans. Follow-up mangroves are Derris trifoliata and Sesuvium portulacastrum. Based on the results of the study, it was found that the associated mangrove has a greater density than the true mangrove species. The form of associated mangrove growth that is still classified as seedlings makes its density high (Table 1). The number of seedlings seen is greater, but its presence is only in certain plots. The high density of seedlings is due to recurrence and drooping growth so that the vegetation lives in groups (Noor et al. 2006). The highest density in the follow-up mangrove comes from the vegetation of $D$. trifoliata. The density of $D$. trifoliata is 14,801 individuals $/ 1000 \mathrm{~m}^{2}$. The species density of $S$. portulacastrum is 2,233 individuals $/ 1000 \mathrm{~m}^{2}$ (Table 1 ).

Meanwhile, the form of growth in true mangroves has a higher number of tillers than the number of trees and seedlings. The presence of higher tillers indicates that the mangrove forest is still in a process of development (Hidayat et al. 2010). The type of true mangrove vegetation with the highest density is the type of A. marina with a density of 614 individuals $/ 1000 \mathrm{~m}^{2}$ (Table 1 ). According to Akbar et al. (2008), the abundance of vegetation types of $A$. marina was caused by natural rehabilitation starting in 2000. This rehabilitation process occurred due to sedimentation resulting from river activities and the availability of seed sources from Sungai Raya mangrove forests. Spread is influenced by tidal currents.
Avicennia marina also has the largest dominance value of $92.75 \%$ of the other types (Table 1). The magnitude of the value of dominance indicates the ability of vegetation to compete against nutrients, groundwater, air that is in the soil. Adequate nutrition makes good shoot growth. Good shoot growth causes the ability of this type to compete in obtaining light as the main energy in photosynthesis so that it will affect the growth of all organs including stems, leaves, and root growth. The results of the study are confirmed by the research of Ginting et al. (2016) where the fulfillment of ecological factors in a habitat enables this species to grow well and dominate at each growth level.

The growth and development of mangroves can be influenced by environmental parameters such as salinity. Salinity plays a role in the growth of $A$. marina because the species has habitat in areas with high salinity. While other mangrove vegetations such as associated mangroves are mostly planted by the surrounding community or there is assistance for planting. Salinity measurement results at the study site ranged from 26-34 \%o. The development and growth of ideal mangroves have salinity varies between 0.5-35\% (Hamran et al. 2014). Salinity concentrations at the study site affect the diversity and distribution of vegetation types based on the vegetation adaptation process (Shan et al. 2008). According to Akbar et al. (2008), in Karimunting Bay A. marina is very abundant (dominant) and has been found since 2008 .

Other environmental factors that affect the growth and development of mangrove vegetation are $\mathrm{pH}$ and temperature. The results of measurements of water $\mathrm{pH}$ in the mangrove forest environment showed a value of 7.5- 
8.2. According to Hariphin et al. (2016), waters with a $\mathrm{pH}$ of 7.5 to 8.5 , are ideal $\mathrm{pH}$ conditions for the growth and development of mangroves. The $\mathrm{pH}$ concentration will affect the process of absorption of nutrients by the roots (El-Mallakh et al. 2014). The $\mathrm{pH}$ condition of mangrove waters at the study site shows $\mathrm{pH}$ concentrations in a relatively neutral to alkaline range which means that it is still classified as a good condition for mangrove growth. This condition shows that environmental conditions support the rapid growth of mangroves. The ideal temperature parameters for mangrove forests range from $20-35^{\circ} \mathrm{C}$ (Noor et al. 2015). Based on the results of measurements at the research location, it has an average temperature of the mangrove forest environment of 30.26 ${ }^{\circ} \mathrm{C}$ with a range of temperature ranges of $29^{\circ} \mathrm{C}-34{ }^{\circ} \mathrm{C}$. Measurements were made during the dry season, where in this season the temperature has increased. This range of temperature can still be tolerated by mangroves. High temperatures indicate that the area is exposed to sufficient sunlight. Exposure to sunlight can help photosynthesis and support the respiration process that functions in the development and growth of mangroves. If the supporting factors of respiration are not met or lacking, the plant will produce energy in itself in small amounts. Poor plant's respiration system will have an impact on the death of plants or indicated by plants drying up (Alwidakdo et al. 2014).

\section{Factor carbon storage potential}

Observation of the weight and volume of logs after being roasted showed the results of wood specific gravity on the trunks of Avicennia marina of $0.71 \mathrm{gr} / \mathrm{cm}^{3}$. Specific gravity that has been obtained in accordance with research by Baderan (2017) showed that the density of A. marina is 0.38 to $0.85 \mathrm{gr} / \mathrm{cm}^{3}$. Based on the research by Bismark et al. (2008), the density of other mangroves such as Rhizophora sp. and Bruguiera sp. has specific gravity of $0.92 \mathrm{~g} / \mathrm{cm}^{3}$ and $0.91 \mathrm{~g} / \mathrm{cm}^{3}$. Meanwhile, according to Syabana and Widiastuti (2018), the study found that the specific gravity of Nypa fruticans is $0.87-1.19 \mathrm{~g} / \mathrm{cm}^{3}$. Some types of mangrove vegetation have specific gravity based on the genus of vegetation. The specific gravity varies for each genus depending on the structure of the wood. The percentage of carbon provides a description of the variation in density or density in wood that can be caused by one factor, namely the ability of each species in the absorption and storage of nutrients (Conti and Diaz 2013). Absorption and storage in large quantities will result in carbohydrates which make the cell walls of the wood greater and equal to greater carbon storage (Tarasov et al. 2018).

Mangrove vegetation height can determine the level of growth in vegetation. Vegetation in the form of tree growth has large carbon storage and little carbon absorption ability because the growth period starts to slow down (Hasanuzzaman et al. 2018). Whereas sapling-level vegetation has the potential for carbon sequestration and large storage for growth and in seedlings, it has a large absorption ability and low storage. This is because the amount of juvenile wood (young wood) and the water content contained in the seedling stems are still very high, resulting in a low carbon value. In addition, recurrent vegetation and degraded vegetation classified as herbaceous have non-woody stems and high water content (Hasanuzzaman et al. 2018).

The diameter of the tree also determines the potential for carbon storage. The larger the diameter, the more polysaccharide compounds that show the potential for higher carbon content. The cell wall consists of three polymer components namely cellulose (40-50\%), hemicellulose (15-25\%), and lignin (20-25\%) and other substances (5-10\%) (Zeng et al. 2017). Stem biomass based on stand volume or BV is an estimator of biomass content based on vegetation stems. BV values are used when BEF values are not available and only have a specific gravity value for each vegetation (Forestry Research and Development Agency, 2013). The Biomass Expansion Factor (BEF) value is used to convert inventory data (volume) into formulated biomass (Forestry Research and Development Agency 2013).

Carbon storage is very much influenced by biomass because organic carbon as a result of syntheses will be stored as biomass. The statement is confirmed in the research (Prasetyo et al. 2017), that the amount of carbon storage is directly proportional to the amount of biomass in vegetation. The largest form of storage of vegetation biomass comes from the trunk of the vegetation. Laboratory test results show \%C carbon in Avicennia marina vegetation of $55.52 \%$ or 0.5552 . The value of $\% \mathrm{C}$ in A. marina shows greater results than the standard \% $\mathrm{C}$ for tree species. These results indicate that in the mangrove trunk there is around $55.52 \%$ carbon content.

Based on the calculation results, it is found that in the area of the research sample location, the carbon storage size of each type of mangrove is different. This difference is influenced by the number of mangroves, biomass and \% $\mathrm{C}$ (carbon) of each mangrove type. Avicennia marina vegetation as dominant vegetation certainly has greater carbon storage potential compared to other vegetation which is 79,782 tons/ha (Table 2). The research location is a secondary mangrove forest that is dominated by $A$. marina vegetation as its ecosystem compiler. Vegetation of A. marina acts as pioneer vegetation in mangrove zonation due to the small area of the forest. This is different from primary forests which have large forest areas so that they have more complex mangrove zoning. Based on the area, the amount of vegetation and diversity of mangrove vegetation will influence the potential for carbon storage. The area is related to the amount of vegetation and biomass stored in the mangrove forest substrate (Rumengan et al. 2018). Mangrove area of 138.2 ha in 2019 was able to store carbon reserves of about 99.231 tons/ha or as much as $13,713,717$ tons (Table 2).

\section{Modeling of carbon storage potential}

The Bengkayang District coast has experienced erosion and sedimentation (Akbar et al. 2017). The erosion that occurred in the Sungai Raya section has caused sedimentation in the coastal part of Karimunting Bay. Sedimentation occurs in the coastal part of Karimunting Bay because of the tendency of the distribution of 
sedimentation from the north to the sea, so the proportion of mud is greater than that of clay. Coastal sediments are dominated by silt (mud) with higher organic content of 2.25-7.31\% (Lanuyu and Yusuf 2018).

The coast of Karimunting Bay experienced sedimentation resulting in the addition of mangrove forests (Akbar et al. 2008). According to the Regional Environmental Impact Management Agency of West Kalimantan, (2003) in Akbar et al. (2008) that in general the abrasion that occurs in West Kalimantan is $35 \mathrm{~m} /$ year, so that countermeasures are made with breakwater development accompanied by planting Rhizophora species. Breakwater was constructed by the West Kalimantan Provincial Government with a length of $16 \mathrm{~km}$ and in 2008 with a length of $1.8 \mathrm{~km}$. Breakwater construction also took place in 2015 according to the surrounding community. The addition of mangrove areas naturally and efforts to improve the coast of Karimunting Bay support the mangrove forest rehabilitation process.

The analysis showed that the increase in mangrove forest area is around $10 \mathrm{ha} /$ year (Table 3 ). This increase is accompanied by a large amount of carbon storage of 991,570 tons/year (Table 3). The potential for carbon storage for the past 10 years is 9,915,697 tons $\mathrm{C}$, equivalent to carbon dioxide $\left(\mathrm{CO}_{2}\right)$ storage of $36,390,608$ tons or $3,639,061$ tons/year. Absorption of carbon dioxide in the mangrove forests of Karimunting Bay plays a role of $0.0044 \%$ to efforts in reducing GHG emissions to achieve the conditional target according to the Nationally Determined Contribution (NDC) in 2030 of 834 million tons of $\mathrm{CO}_{2}$ (Ministry of Environment and Forestry of the Republic of Indonesia, 2017). The emission reduction target in 2030 based on Nationally Determined Contribution (NDC) aims to prevent the temperature of the earth from increasing to $2^{\circ} \mathrm{C}$ (Isnan 2018).

Mangrove ecosystems can be used as a mitigation of global warming (Sitoe et al. 2014) because they can increase carbon sequestration and storage and prevent erosion (decreasing the extent of mangrove forests). According to Herianto and Subiandono (2016), mangroves have enormous potential in mitigating global warming by absorbing carbon dioxide $\left(\mathrm{CO}_{2}\right)$ gas from the atmosphere at a higher rate per unit area, compared to absorption from terrestrial forests. In addition, according to Akbar et al. (2017), mangroves can also prevent erosion by holding and breaking waves so that coastal erosion can be reduced. The existence of mangroves naturally provides environmental services in the form of the ability to repair damage and pollution that exists on the coast of Karimunting Bay.

In conclusion, the mangrove ecosystems on the Karimunting Bay have a total density of 17,748 individuals/hectare. They consist of six species, namely Avicennia marina, Bruguiera gymnorrhiza, Nypa fruticans, Rhizophora stylosa, Derris trifoliata, and Sesuvium portulacastrum. The largest mangrove storage potential is A. marina with 79,782 tons/hectare and the smallest is $R$. stylosa species with 9,347 tons/hectare. The presence of mangrove ecosystems in Karimunting Bay has increased by 10 hectares/year for the last 10 years. This area increase is directly proportional to the addition of carbon deposits of
991,570 tons. The carbon storage potential is proportional to the carbon dioxide absorption capacity of $36,390,608$ tons. This carbon dioxide absorption is equivalent to $0.0044 \%$ which plays a role in reducing GHG emissions with conditional targets according to the Nationally Determined Contribution (NDC) in 2030.

\section{ACKNOWLEDGEMENTS}

This research is one of the studies funded by the research fund of the Faculty of Engineering, Tanjungpura University Research under contract Number: 2499/UN22.4/KU/2019.

\section{REFERENCES}

Akbar AA, Djohan TjS, Sartohadi J. 2008. Mangrove ecosystems and abrasion on the coast of West Kalimantan. Geograph Forum 2 (1): 6071.

Akbar AA, Sartohadi J, Djohan TjS, Ritohardoyo S. 2017. The breakwater role on the rehabilitation of coastal and mangrove forests in West Kalimantan, Indonesia. J Ocean Coast Manag 138 (1): 50-59. DOI: 10.1016/j.ocecoaman.2017.01.004.

Alavaisha E, Mangora MM. 2016. Carbon stock in the small estuarine mangrove of Geza and Mtimbwani, Tanga, Tanzania. For Res 1-11. DOI: $10.1155 / 2016 / 2068283$.

Alongi DM. 2014. Carbon cycling and storage in mangrove forests. Annu Rev Mar Sci 6, 195-219.

Alwidakdo A, Azham Z, Kamarubayana L. 2014. Study of mangrove growth in mangrove forest rehabilitation activities in Tanjung Limau Village, Muara Badak Sub-district, Kutai Kartanegara District. Agrifor 13 (1): 11-18. [Indonesian]

Baderan DW. 2017. Gorontalo Mangrove Forest Carbon Absorption. CV. Budi Utama, Yogyakarta. [Indonesian]

Bismark, Subiandono E, Heriyanto. 2008. Diversity and potential types and carbon content of mangrove forests in the Siberut Subelen River, West Sumatra. For Res Nat Conserv 5 (3): 297-306.

Chow J. 2017. Mangrove management for climate change adaptation and sustainable development in coastal zones. Sustain For 37 (2): 139156. DOI: $10.1080 / 10549811.2017 .1339615$

Conti G, Diaz S. 2013. Plant functional diversity and carbon storage - An empirical test in semi-arid forest ecosystems. Ecology 101 (1): 18-28. DOI: 10.1111/1365-2745.12012.

Eid EM, Shaltout KH. 2016. Distribution of organic carbon soil in the mangrove Avicennia marina (Forssk.) Vierh. along the Egyptian Red Sea coast. Reg Stud Mar Sci 3: 76-82. DOI: 10.1016 /j.rsma.2015.05.006.

El-Mallakh TV, Gao Y, El-Mallakh RS. 2014. The effect of simulated acid rain on growth of root systems of Scindapsus aereus. Plant Biol 5 (5187): 13-15. DOI: $10.4081 / \mathrm{pb} .2014 .5187$.

Elzaki OT, Khider TO. 2013. Physical and mechanical properties of Cupressus lusitanica as a potential timber tree for Sudan. For Prod Ind 2 (1): 43-46.

English S, Wilkinson C, Baker V. 1994. Survey manual for tropical marine resources. ASEAN Australia Marine Science Project's Living Coastal Resource, Australia.

Ewel KE, Twilley RR, Ong JE. 1998. Different kinds of mangrove forests provide different goods and services. Global Ecol Biogeogr Lett 7 (1): 83-94.

Food and Agriculture Organization (FAO) of The United Nations. 1994. Mangrove Forest Management Guidelines. FAO, Rome.

Forestry Research and Development Agency. 2013. Guidelines for using the allometric model for estimating biomass and forest carbon stocks in Indonesia. Research and Development Center for Conservation and Rehabilitation, Forestry Research and Development Agency-Ministry of Forestry, Bogor. [Indonesian]

Gillerot L, Vlaminck E, Ryck DJRD, Mwasaru DM, Beeckman H, Koedam N. 2018. Inter-and intraspecific variation in mangrove 
carbon fraction and wood specific gravity in Gazi Bay, Kenya. Ecosphere 9 (6): 1-17. DOI: 10.1002/ecs2.2306.

Ginting ZA, Marunung TF, Sisillia L. 2017. Vegetation analysis in village forest areas in Nanga Yen Village, Hulu Gurung Sub-district, Kapuas Hulu District. Sustain For 5 (3): 713-720. [Indonesian]

Hamran, Linda R, Lovadi I. 2014. Analysis of mangrove vegetation in Sebubus Village, Paloh Sub-district, Sambas District. Protobiont 3 (2): 201-208. [Indonesian]

Hariphin, Linda R, Rusmiyanto E. 2016. Analysis of vegetation of mangrove forests in the Serukam River estuary area of Bengkayang District. Protobiont 5 (3): 66-72. [Indonesian]

Hasanuzzaman M, Prasad MNV, Fujita M. 2018. Cadmium Toxicity and Tolerance in Plants: from Physiology to Remediation. Academic Press, United States of America.

Herianto, Subiandono E. 2016. The role of mangrove biomasses in saving carbon in Kubu Raya, West Kalimantan. Policy Anal 13 (1): 1-12.

Hidayat T, Kusmana C, Tiryana T. 2010. Species composition and structure of secondary mangrove forests in East Rawa, Central, Java, Indonesia. Bioflux 10 (4): 675-686.

Hong LC, Hemati ZH, Zakaria RM. 2017. Carbon stock evaluation of mangrove forest selection in Peninsular Malaysia and its potential market value. Environ Sci Manag 20 (2): 77-87.

Isnan W. 2018. Kebijakan pengurangan emisi gas rumah kaca dari sektor penggunaan lahan dan perubahan tatat guna lahan kehutanan (LULUCF). Jurnal Teknis Eboni 15 (1): 29-39. [Indonesian]

Kerte KA, Shuaibu RA, Nyomboi T, Oyawa WO. 2014. Structural performance of short mangrove reinforced concrete columns. Eng Sci Emerg Technol 7 (2): 568-577.

Kreeger D, Padeletti A. 2010. Method for Loss-On-Ignition (LOI) Weight Analyzes. Partnership for the Delaware Estuary. PDE Method.

Lanuyu M, Yusuf S. 2018. Bed sediment distribution in the river estuary and coastal sea of Malili (South Sulawesi, Indonesia). Mar Sci 4 (2) $59-62$.

Liu H, Ren H, Sharks D, Wang W, Liao B, Cao Q. 2014. Carbon stocks and potential carbon storage in the forest of China. Environ Manag 133: 86-93. DOI: 10.1016/j.jenvman.2013.11.037.

Ministry of Environment and Forestry. 2017. GHG inventory report, monitoring, reporting and verification 2017. Directorate General of Climate Change Control, Jakarta. [Indonesian]

Noor T, Batool N, Mazhar R, Ilyas N. 2015. Effects of siltation, temperature and salinity on mangrove plants. Eur Acad Res 2 (11): 14172-14179.
Noor YR, Khazali, Suryadiputra. 2006. Guide to Introduction of Mangroves in Indonesia. PHKA/WI-IP. Bogor. [Indonesian]

Perez A, Machado W, Gutierrez D, Borges AC, Patchineelam SR, Sanders CJ. 2018. Carbon accumulation and storage capacity in mangrove sediments three decades after deforestation within a eutrophic bay. Mar Pollut Bull 126: 275-280. DOI: 10.1016/j.marpolbul.2017.11.018

Prasetyo, Dimas PB, Nuraini, Ria AT, Supriyantini. 2017. Estimation of carbon stock and mangrove vegetation at the mangrove area of Ujung Piring, Jepara District. Mar Aquat Resour Conserv Co-existence 2 (1): $38-45$.

Ritohardoyo S, Akbar AA, Sartohadi J, Djohan TS. 2017. Public participation in the utilization and rehabilitation of coastal natural resources (Case study of coastal erosion in West Kalimantan). Degraded Mining Land Manag 4 (2): 739-747. DOI: DOI: 10.15243/jdmlm.2017.042.739

Rumengan AP, Mantiri DMH, Rompas R, Hutahaean A, Kepel TL, Paruntu CP, Kepel RC, Gerung GS. 2018. Carbon stock assessment of mangrove ecosystems in Totok Bay, Southeast Minahasa District, North Sulawesi, Indonesia. AACL Bioflux 11 (4): 1280-1288.

Shan L, Renchao Z, Suisui D, Suhua S. 2008. Adaptation to salinity in mangrove: Implication on evolution of salt-tolerance. Chin Sci Bull 53 (11): 1708-1715.

Sitoe AA, Mandlate LJC, Guedes BS. 2014. Biomass and carbon stocks of Sofala bay mangrove forests. Forests 5 (8): 1967-1981.

Sondak CFA, Chung IK. 2015. Potential blue carbon from coastal ecosystems in the Republic of Korea. Ocean Sci J 50: 1-8.

Syabana DK, Widiastuti R. 2018. Physical characteristics of Nipa fruticans Fiber. Dyn Crafts Batik 35 (1): 9-14.

Tarasov D, Leitch M, Fatehi P. 2018. Lignin-carbohydrate complexes: Properties, applications, analyzes and methods of extraction. Biotechnol Biofuels 11 (269): 1-28. DOI: 10.1186/s13068-018-12621

Vo Q, Kuenzer C Oppelt N. 2015. How remote sensing supports mangrove ecosystem service valuation: A case study in Ca Mau Province, Vietnam. Ecosyst Serv 14: 67-75. DOI: 10.1016/j.ecoser.2015.04.007.

Wang Min, Cao Wenzhi, Jiang Chao, Yan Yiyun, Guan Q. 2018. Potential ecosystem service value of forest management in southeastern China using high-resolution satellite data. Estuar Coast Shelf Sci 209: 30-40. DOI: 10.1016/j.ecss.2018.05.023

Zeng Y, Himmel ME, Ding SY. 2017. Visualizing chemical functionality in plant cell walls. Biotechnol Biofuels 10 (263): 1-16. DOI: 10.1186/s13068-017-0953-3. 